\title{
Appendix Goblet Cell Carcinoid
}

National Cancer Institute

\section{Source}

National Cancer Institute. Appendix Goblet Cell Carcinoid. NCI Thesaurus. Code C3689.

An invasive mixed adenoneuroendocrine carcinoma of the appendix characterized by a submucosal growth and the presence of neoplastic signet-ring cells resembling goblet cells of the intestine. 